Check for updates

Cite this: RSC Adv., 2018, 8, 41040

Received 26th August 2018 Accepted 3rd December 2018 DOI: $10.1039 / c 8 r a 07115 b$

rsc.li/rsc-advances

\section{The influence of molecular structure on collision radius for optical sensing of molecular oxygen based on cyclometalated Ir(III) complexes $\dagger$}

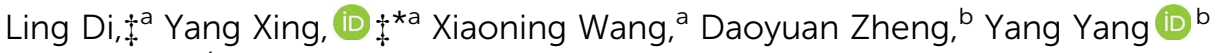 \\ and Fayun $\mathrm{Li}^{* a}$
}

\begin{abstract}
Three triphenylamine (TPA) substituted cyclometalated $\operatorname{Ir}\left(\right.$ III) complexes $\operatorname{IrA1}$, IrA2, and IrA3 based on $\operatorname{Ir}(\mathrm{ppy})_{3}$ were synthesized and applied as phosphorescent probes for the monitoring of molecular oxygen. The phosphorescence intensity of all the Ir(III) complexes in tetrahydrofuran (THF) was gradually quenched with an increase of oxygen concentration. The increase of TPA substituents on the meta-position of 2phenylpyridine (IrA1-IrA3) gradually improved the oxygen sensitivity of cyclometalated Ir(II) complexes. IrA3 showed the highest oxygen sensitivity in THF with a $K_{\mathrm{SV}}^{\mathrm{app}}$ of $204.8 \mathrm{bar}^{-1}$ and a limit of detection (LOD) of 0.27 mbar. The relationship between molecular structure and the collision radiuses $(\sigma)$ of all the Ir(III) complexes has been investigated on the basis of the Demas model and the fundamental expression of luminescence quenching systems by oxygen. The ratio of collision radiuses are $\sigma_{\operatorname{lrA} 1} / \sigma_{\operatorname{lr}(\mathrm{ppy})_{3}}=1.27 \pm$ $0.05, \sigma_{\operatorname{lrA2} 2} / \sigma_{\operatorname{lr}(\text { ppy })_{3}}=1.72 \pm 0.10$, and $\sigma_{\operatorname{lrA} 3} / \sigma_{\operatorname{lr}(\text { ppy })_{3}}=2.13 \pm 0.07$, respectively. The introduction and increase of TPA substituents can obviously increase the collision radiuses of cyclometalated Ir(III) complexes which leading to potential oxygen sensitivity. And the incremental effect of collision radiuses caused by the introduction of TPA substituents resulted in outstanding oxygen sensitivity of IrA3. The results demonstrate for the first time evidence between molecular structure and oxygen sensitivity of the emitters for optical sensing.
\end{abstract}

\section{Introduction}

Optical sensors have attracted a great deal of interest for oxygen quantification due to the advantages of excellent reversibility, quick response, minimal invasiveness and suitability for monitoring of oxygen in gaseous condition and in solution (dissolved oxygen). ${ }^{\mathbf{1 - 4}}$ Various formats of optical oxygen sensors have been developed including fibre-optic sensors, micro- or nanoparticles, paints and so on. ${ }^{5-9}$ Optical oxygen sensors depended on the dynamic (diffusion-controlled) quenching of emitters by molecular oxygen which is characterized by the Stern-Volmer equation (eqn (1) $)^{\mathbf{1 0}}$

$$
\frac{I_{0}}{I}=\frac{\tau_{0}}{\tau}=1+k_{\mathrm{q}} \tau_{0}\left[\mathrm{O}_{2}\right]
$$

where $I$ and $\tau$ are the intensity and decay time of the emitter respectively. $I_{0}$ and $\tau_{0}$ are the corresponding values in the

${ }^{a}$ College of Chemistry, Chemical Engineering, and Environmental Engineering, Liaoning Shihua University, Fushun 113001, China. E-mail: xingyang@lnpu.edu.cn; flilnpu@163.com; Tel: +86-24-56860865

${ }^{b}$ State Key Laboratory of Molecular Reaction Dynamics, Dalian Institute of Chemical Physics, Chinese Academy of Sciences, Dalian 116023, China

$\dagger$ Electronic supplementary information (ESI) available: Phosphorescent emission decay curves and cyclic voltammogram. See DOI: 10.1039/c8ra07115b

\$ These authors contributed to this work equally. absence of oxygen. $k_{\mathrm{q}}$ means bimolecular quenching constant and $\left[\mathrm{O}_{2}\right]$ expresses the molar concentration of oxygen. $I_{0} / I$ (or $\tau_{0} /$ $\tau)$ versus $\left[\mathrm{O}_{2}\right]$ are linear with slopes of $k_{\mathrm{q}} \tau_{0}$. In principle, oxygen sensitivity is roughly in proportion to phosphorescent decay time of the emitter. ${ }^{\mathbf{1 1 - 1 4}}$ State of the art optical oxygen sensors are mainly made up of phosphorescent iridium, platinum complexes, $\mathrm{BF}_{2}$, and aluminum chelates, which possess decay time varying in long range of microseconds to milliseconds. ${ }^{15-19}$

To prevent potential interference and loss of emitters, polymer matrices are often used as permeation-selective barrier. ${ }^{20-24}$ In eqn (2), the oxygen concentration in the polymer matrix is proportional to the oxygen partial pressure $\left(p_{\mathrm{O}_{2}}\right)$ just above the film. And the proportionality constant $S_{\mathrm{O}_{2}}$ is the oxygen solubility in organic solvents and polymer matrices defined by Henry's law. $^{25}$

$$
\left[\mathrm{O}_{2}\right]=S_{\mathrm{O}_{2}} p_{\mathrm{O}_{2}}
$$

Because quenching of phosphorescence is caused by diffusion between emitters and molecular oxygen, the bimolecular quenching constant $k_{\mathrm{q}}$ by the expression (eqn (3)) ${ }^{26}$

$$
k_{\mathrm{q}}=\frac{4 \pi N_{\mathrm{A}}}{1000} \sigma \alpha D_{\mathrm{O}_{2}}
$$


$D_{\mathrm{O}_{2}}$ is the diffusion coefficient of oxygen in solvents or matrices, and $N_{\mathrm{A}}$ is Avogadro's constant. $\alpha$ represents the probability that a collision leads to quenching. Many authors set $\alpha$ equal to unity for phosphorescence quenching by oxygen in analyzing data. $^{27-31} \sigma$ is the collision radius of an emitter molecule to molecular oxygen. Upon substitution of eqn (2) and (3) into (1), the fundamental expression (eqn (4)) governing luminescence quenching by oxygen for systems in equilibrium with oxygen was obtained. ${ }^{26}$

$$
\frac{I_{0}}{I}=\frac{\tau_{0}}{\tau}=1+\frac{4 \pi \alpha N_{\mathrm{A}}}{1000}\left(D_{\mathrm{O}_{2}} S_{\mathrm{O}_{2}}\right)\left(\sigma \tau_{0}\right) p_{\mathrm{O}_{2}}
$$

On one hand, oxygen sensitivity could be effectively enhanced by using of high oxygen permeable matrix. The extent of quenching markedly depends on the oxygen permeability $\left(P_{\mathrm{O}_{2}}\right)$ of the matrix, where $P_{\mathrm{O}_{2}}$ is defined as the product of $D_{\mathrm{O}_{2}}$ and $S_{\mathrm{O}_{2}}\left(P_{\mathrm{O}_{2}}=D_{\mathrm{O}_{2}} S_{\mathrm{O}_{2}}\right)$. Much work so far has focused on the modification of the matrices with fluorinated substituents, etc. $^{32-35}$ On the other hand, decay time $\left(\tau_{0}\right)$ of the emitters also determined oxygen sensitivity of the sensors. Considerable research efforts have been devoted to the design and synthesis of emitters with long triplet decay time. ${ }^{3,11,36,37}$ Borisov and coworkers reported an aluminium chelate $\mathrm{Al}(\mathrm{HBANPF})_{3}$ with ultra-long decaying phosphorescence $(350 \mathrm{~ms})$. Al(HBANPF) $)_{3}$ which were immobilized in perfluorinated polymers can monitor oxygen in nearly anoxic system. ${ }^{3}$ Zhao et al. investigated the oxygen sensitivity of two dual-emissive Pt(II) complexes Pt-1 and Pt-2. And Pt-2 with long phosphorescent decay time $(3.75 \mu \mathrm{s})$ exhibited higher oxygen sensitivity (136.0 bar $^{-1}$ ) compared with short-decay Pt-1 (1.53 $\mu \mathrm{s}, 45.1$ bar $\left.^{-1}\right) .{ }^{11}$ Besides $P_{\mathrm{O}_{2}}$ and $\tau_{0}$, the collision radius $(\sigma)$ of the emitter is the third factor to oxygen sensitivity of emitters which was often ignored by researchers. In some cases, oxygen sensitivity and decay time of emitters are not proportional in the same microenvironment (emitters were immobilized in the same matrix with the same preparation method)., ${ }^{7,22,36-43}$ For instance, neutral blue emitting cyclometalated Ir(III) complexes Ir-1 and Ir- 2 were immobilized in a nanostructured aluminum oxide-hydroxide matrix named AP200/19. Ir-2 with long
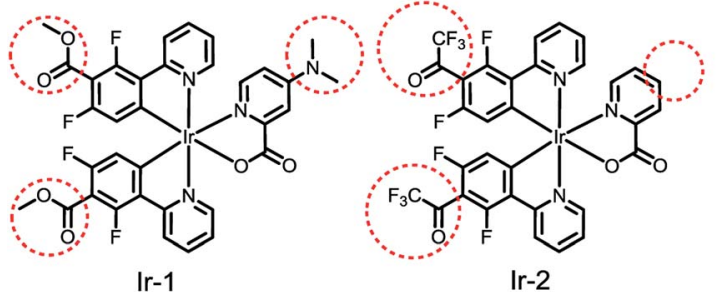

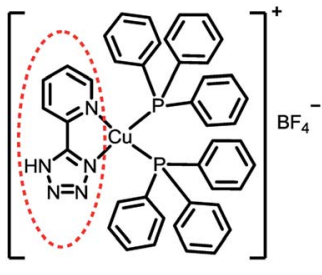

Cu-1

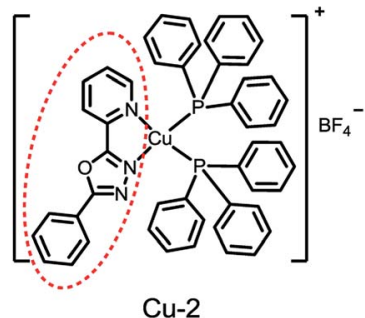

$\mathrm{Cu}-2$
Fig. 1 Chemical structure of phosphorescent complexes $|r-1| r-$,2 , $\mathrm{Cu}-1$, and $\mathrm{Cu}-2$. Structure variations of intraligands of Ir-1 and Ir-2, $\mathrm{Cu}-1$ and $\mathrm{Cu}-2$ are showed in red circles.

phosphorescent decay time showed lower oxygen sensitivity compared to short-decay Ir-1 (Fig. 1). ${ }^{40}$ Phosphorescent decay time of $\mathrm{Cu}(\mathrm{I})$ complex $\mathrm{Cu}-2$ is 17 -fold longer than $\mathrm{Cu}-1$, however the oxygen sensitivity of $\mathrm{Cu}-2$ is $72 \%$ of $\mathrm{Cu}-1$ (Fig. 1). ${ }^{44}$ Obviously, changes of molecular structure of the emitter lead to the changing of the collision radius, and then affect oxygen sensitivity. For quantification of low concentrations or low partial pressures of oxygen, researchers would like to design phosphorescent emitters with long decay time and then immobilized them in the matrices with extremely high oxygen permeability. To the best of our knowledge, no systematic study concerning how change of molecular structure affect the collision radius $(\sigma)$ of a phosphorescent emitter for optical oxygen sensing.

Triphenylamine (TPA) substituent is an important structural motif in numerous dye-sensitized solar cells (DSSCs) and organic electroluminescence materials because of features, such as non-co-planarity of the three phenyl substituents, strong electron-donating nature and high light-to-electrical energy. ${ }^{\mathbf{4 5 , 4 6}}$ Herein, we report a systematic investigation of the

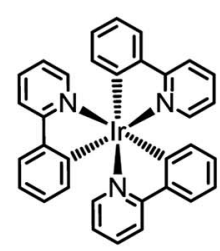

$\operatorname{Ir}(\mathrm{ppy})_{3}$

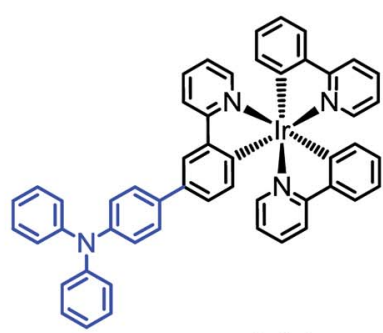

IrA1

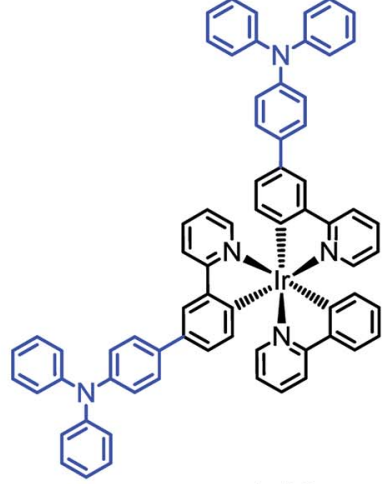

IrA2

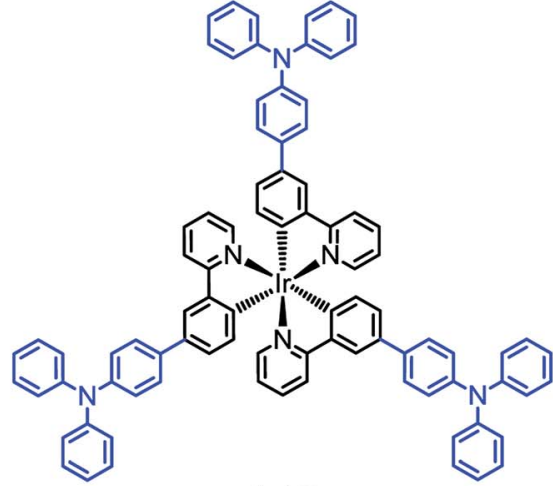

IrA3

Scheme 1 Structures of the cyclometalated Ir(III) complexes. 
Table 1 Photophysical data of all the Ir(III) complexes

\begin{tabular}{|c|c|c|c|c|}
\hline Complexes & Absorption $(293 \mathrm{~K}) \lambda_{\mathrm{abs}}{ }^{a}(\mathrm{~nm})$ & $\begin{array}{l}\text { Emission maxima } \\
\lambda_{\mathrm{em}}(\mathrm{nm})(293 \mathrm{~K})\end{array}$ & $\Phi_{\mathrm{p}}^{b}$ & $\tau^{c}(\mu \mathrm{s})$ \\
\hline $\operatorname{Ir}(\text { ppy })_{3}$ & 250 (1.87), 284 (3.75), 379 (1.12), 411 (0.71), 456 (0.27), 490 (0.12) & 511 & 0.40 & 2.38 \\
\hline IrA2 & 254 (1.27), $287(4.12), 334(5.07), 405(0.60), 480(0.10)$ & 522 & 0.49 & 2.51 \\
\hline IrA3 & 262 (4.18), 296 (8.42), 332 (9.48), 404 (1.32), $472(0.27)$ & 522 & 0.53 & 2.42 \\
\hline
\end{tabular}

${ }^{a}$ Measured in THF at a concentration of $10^{-5} \mathrm{M}$ and $\log \varepsilon$ values are shown in parentheses and extinction coefficients $\left(10^{4} \mathrm{M}^{-1} \mathrm{~cm}^{-1}\right)$ are shown in parentheses. ${ }^{b}$ In degassed THF relative to $\left[\operatorname{Ir}(\mathrm{ppy})_{3}\right]\left(\Phi_{\mathrm{p}}=0.40\right),\left(\lambda_{\mathrm{ex}}=400 \mathrm{~nm}\right) .{ }^{c}$ Measured in degassed THF at a sample concentration of $c a$. $10^{-5} \mathrm{M}$ and the excitation wavelength was set at $355 \mathrm{~nm}$ for all the samples at $293 \mathrm{~K}$.

relationship between the molecular structure and the collision radius $(\sigma)$ of the emitter by modification of cyclometalated $\operatorname{Ir}($ III) complexes $\operatorname{Ir}(\mathrm{ppy})_{3}$ with incremental introduction of TPA substituents. Chemical structures of cyclometalated $\operatorname{Ir}(\mathrm{III})$ complexes IrA1, IrA2, $\operatorname{IrA} 3$ and $\operatorname{Ir}(\mathrm{ppy})_{3}$ are shown in Scheme 1.

\section{Result and discussion}

\subsection{Photophysical and electrochemical property}

The photophysical properties of IrA1-IrA3 and $\operatorname{Ir}(\mathrm{ppy})_{3}$ are exhibited Table 1 . The absorptions of $250-375 \mathrm{~nm}$ which belong to $\pi-\pi^{*}$ transitions in intraligands enhanced with the incremental introduction of TPA substituents on meta-position of 2phenylpyridine ligands (Fig. 2). The phenomenon also caused the increase of phosphorescence quantum efficiency of $\operatorname{Ir}(\mathrm{ppy})_{3}$ (0.40), IrA1 (0.48), IrA2 (0.49), and IrA3 (0.53) (Table 1). The transient phosphorescence decay for each Ir(III) complex in THF was mono-exponential, and the lifetimes ranged from $2.38 \mu$ s to $2.93 \mu$ s. Compared to $\operatorname{Ir}(\mathrm{ppy})_{3}(2.38 \mu \mathrm{s})$, phosphorescent lifetime of IrA1 $(2.93 \mu \mathrm{s})$ became longer with introducing a TPA substituent on 2-phenylpyridine. Notably, the incremental introduction of TPA substituents on 2-phenylpyridines of $\operatorname{Ir}(\text { ppy })_{3}$ gradually shortened the lifetimes of cyclometalated Ir(III) complexes. Phosphorescent lifetimes of all the $\operatorname{Ir}($ III) complexes are in the sequence of $\operatorname{IrA} 1>\operatorname{IrA} 2>\operatorname{IrA} 3>\operatorname{Ir}(\mathrm{ppy})_{3}$ (Fig. S1, see ESI $\dagger$ ). The emission maxima for all the $\operatorname{Ir}(\mathrm{III})$ complexes are in region from 511 to $522 \mathrm{~nm}$. Based on $\operatorname{Ir}(\mathrm{ppy})_{3}$, the emission maxima of IrA1-IrA3 shifts to a longer wavelength

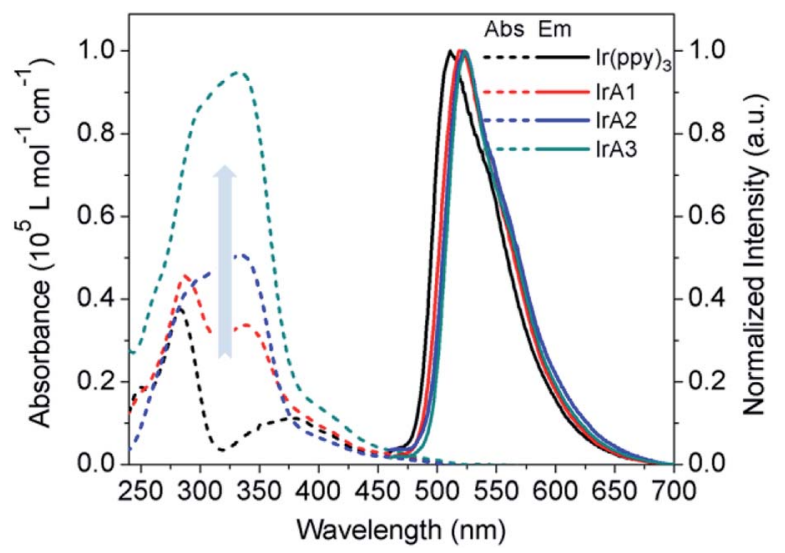

Fig. 2 Absorption and emission spectra of IrA1-IrA3 and Ir(ppy) $10^{-5} \mathrm{M}$ in degassed THF, $25^{\circ} \mathrm{C}$. when increasing TPA substituents at the meta-position on benzene ring of 2-phenylpyridine ligands. The change in emission color of all the $\operatorname{Ir}(\mathrm{III})$ complexes were quantified with CIE coordinates of $\operatorname{Ir}(\mathrm{ppy})_{3}(0.2750,0.6268)$, IrA1 (0.2977, $0.6354)$, IrA2 $(0.3184,0.6228)$, and $\operatorname{IrA} 3(0.3164,0.6341)$ in Fig. S2 (see ESI $\dagger$ ). The electrochemical properties of IrA1-IrA3 and $\operatorname{Ir}(\mathrm{ppy})_{3}$ were examined using cyclic voltammetry (Fig. S3, see ESI $\dagger$ ). All the cyclometalated Ir(III) complexes showed reversible oxidation waves. The oxidation potentials of IrA1-IrA3 and $\operatorname{Ir}(\text { ppy })_{3}$ are $0.78 \mathrm{~V}, 0.77 \mathrm{~V}, 0.78 \mathrm{~V}$, and $0.84 \mathrm{~V}$, respectively, which reflected the donor character of TPA groups. The frontier orbital energy levels of all the $\operatorname{Ir}($ III) complexes are given in Table S1 (see ESI†).

\subsection{Theoretical calculations}

Density functional theory (DFT) calculations were performed in order to estimate the ground-state energy levels and electron density distributions of the orbitals of IrA1-IrA3 and $\operatorname{Ir}(\mathrm{ppy})_{3} \cdot{ }^{47}$ And the ground-state geometry of were optimized under the polarizable continuum model (PCM, solvent $=$ THF) of the selfconsistent reaction field (SCRF). The HOMO and LUMO isosurfaces displayed in Fig. 3 have $\pi$ symmetry with opposite phases above and below the molecular plane. The LUMOs of IrA1-IrA3 and $\operatorname{Ir}(\mathrm{ppy})_{3}$ consist of a mixture of 2-phenylpyridine moieties. The HOMO of $\operatorname{Ir}(\mathrm{ppy})_{3}$ is predominantly distributed on the benzene rings of 2-phenylpyridine ligands and Pt atom. The TPA moieties, benzene rings of 2-phenylpyridine ligands and Pt atoms contribute the HOMOs of IrA1-IrA3. The introduction of a TPA substituent on 2-phenylpyridine caused the delocalization of electron from 2-phenylpyridine moieties to the TPA moiety with energy rise $(0.29 \mathrm{eV})$ of HOMO of IrA1. While the incremental introduction of TPA substituents on 2-phenylpyridines have little effect on the HOMOs of IrA2 and IrA3 (Fig. 3).

The low-lying excited states of the singlet $\left(\mathrm{S}_{1}\right)$ and the triplet $\left(\mathrm{T}_{1}\right)$ of IrA1-IrA3 and Ir(ppy $)_{3}$ were also studied with the timedependent DFT calculations under PCM model (solvent $=$ THF) based on the optimized ground state geometry (Table 2). ${ }^{47}$ The calculated $\mathrm{S}_{1}$ to $\mathrm{T}_{1}$ energy gaps of IrA1-IrA3 and $\operatorname{Ir}(\mathrm{ppy})_{3}$ are $0.33 \mathrm{eV}, 0.31 \mathrm{eV}, 0.30 \mathrm{eV}$, and $0.29 \mathrm{eV}$, respectively. The orbitals are involved in HOMO-3, HOMO-2, HOMO-1, HOMO, LUMO, and LUMO+1. The $\mathrm{S}_{1}$ and $\mathrm{T}_{1}$ states of all the $\operatorname{Ir}(\mathrm{III})$ complexes were mainly assigned as HOMO to LUMO of electron transition. Similar to $\operatorname{Ir}(\mathrm{ppy})_{3}$, the $\mathrm{S}_{1}$ state and $\mathrm{T}_{1}$ state of IrA3 


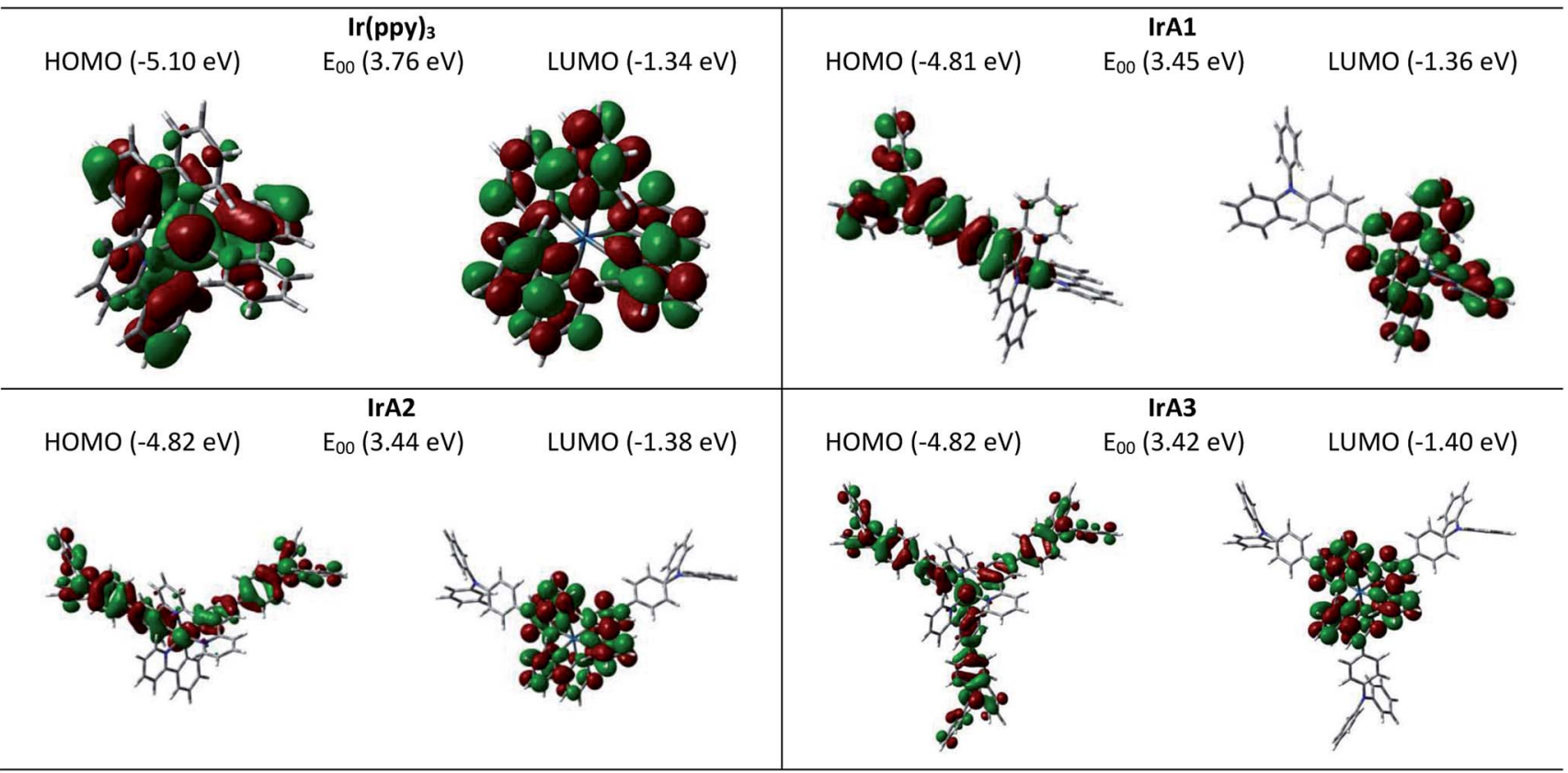

Fig. 3 HOMOs and LUMOS of IrA1-IrA3 and Ir(ppy) ${ }_{3}$ for the ground state geometry. Calculated by DFT/PCM = THF at the B3LYP/6-31G(d)/ LanL2DZ level using Gaussian 16.

were rendered with considerable nature of IL, mixed with MLCT character. The $S_{1}$ state and $T_{1}$ state of IrA1 were rendered with nature of LLCT, MLCT character. And the $S_{1}$ state and $T_{1}$ state of IrA2 were rendered with nature of IL, LLCT, mixed with MLCT character (Table 2 and Fig. S4 see $\mathrm{ESI}_{\dagger}^{\dagger}$ ).

\subsection{Oxygen sensing}

Purified tetrahydrofuran (THF) was selected as dispersion phase for the bimolecular quenching process (Fig. 4). The emission of all the Ir(III) complexes obviously weaken with the increase of oxygen concentration. Above $83 \%$ of original intensity was quenched with $6.8 \%$ oxygen in the air volume. Notably, the emission of IrA3 was almost completely quenched (above 90\% of original intensity) at the oxygen concentration of $6.8 \%$ which showed high oxygen sensitivity.

Demas et al. have investigated the quenching mechanism of oxygen of several emitters in a lot of polymer matrices. ${ }^{\mathbf{4 8 9}}$ The results showed that heterogeneous microenvironment exists in the emitter-contained matrix. The Demas' model ${ }^{48}$ was introduced to fit the Stern-Volmer plots (SVPs) of all the $\operatorname{Ir}(\mathrm{III})$ complexes in THF (Fig. 4) which reads as follows in eqn (5)

Table 2 Electronic excitation energies, oscillator strengths ( $f$ ), configuration-interaction coefficients (Cl), and orbital transition contribution percentages (Co) of the low-lying electronically excited states of IrA1-IrA3 and Ir(ppy) 3

\begin{tabular}{|c|c|c|c|c|c|c|c|}
\hline & \multirow[b]{2}{*}{ Elec. Trans. } & \multicolumn{6}{|c|}{ TDDFT//B3LYP/6-31G(d)/LanL2DZ } \\
\hline & & Energy $^{a}$ & $f^{b}$ & Composition $^{c}$ & $\mathrm{CI}^{d}$ & $\mathrm{Co}^{e}$ & Character $^{f}$ \\
\hline \multirow{2}{*}{$\operatorname{Ir}(\mathrm{ppy})_{3}$} & $\mathrm{~S}_{0} \rightarrow \mathrm{S}_{1}$ & $3.00 \mathrm{eV}, 413 \mathrm{~nm}$ & 0.0109 & $\mathrm{H} \rightarrow \mathrm{L}$ & 0.69705 & $97.18 \%$ & IL, MLCT \\
\hline & $\mathrm{S}_{0} \rightarrow \mathrm{T}_{1}$ & $2.71 \mathrm{eV}, 457 \mathrm{~nm}$ & 0.0000 & $\mathrm{H} \rightarrow \mathrm{L}$ & 0.54221 & $58.80 \%$ & IL, MLCT \\
\hline \multirow[t]{4}{*}{ IrA1 } & $\mathrm{S}_{0} \rightarrow \mathrm{S}_{1}$ & $2.92 \mathrm{eV}, 425 \mathrm{~nm}$ & 0.0238 & $\mathrm{H} \rightarrow \mathrm{L}$ & 0.57752 & $66.71 \%$ & LLCT, MLCT \\
\hline & & & & $\mathrm{H}-1 \rightarrow \mathrm{L}$ & 0.30978 & $19.19 \%$ & LLCT, MLCT \\
\hline & $\mathrm{S}_{0} \rightarrow \mathrm{T}_{1}$ & $2.59 \mathrm{eV}, 479 \mathrm{~nm}$ & 0.0000 & $\mathrm{H} \rightarrow \mathrm{L}$ & 0.40814 & $33.32 \%$ & LLCT, MLCT \\
\hline & & & & $\mathrm{H} \rightarrow \mathrm{L}+1$ & -0.35624 & $25.38 \%$ & LLCT, MLCT \\
\hline \multirow[t]{4}{*}{ IrA2 } & $\mathrm{S}_{0} \rightarrow \mathrm{S}_{1}$ & $2.89 \mathrm{eV}, 429 \mathrm{~nm}$ & 0.0133 & $\mathrm{H} \rightarrow \mathrm{L}$ & 0.60632 & $73.52 \%$ & IL, LLCT, MLCT \\
\hline & & & & $\mathrm{H}-2 \rightarrow \mathrm{L}$ & 0.25367 & $12.87 \%$ & LLCT, MLCT \\
\hline & $\mathrm{S}_{0} \rightarrow \mathrm{T}_{1}$ & $2.58 \mathrm{eV}, 481 \mathrm{~nm}$ & 0.0000 & $\mathrm{H} \rightarrow \mathrm{L}$ & 0.42034 & $35.34 \%$ & IL, LLCT, MLCT \\
\hline & & & & $\mathrm{H}-1 \rightarrow \mathrm{L}+1$ & 0.28375 & $16.10 \%$ & IL \\
\hline \multirow[t]{4}{*}{ IrA3 } & $\mathrm{S}_{0} \rightarrow \mathrm{S}_{1}$ & $2.88 \mathrm{eV}, 431 \mathrm{~nm}$ & 0.0059 & $\mathrm{H} \rightarrow \mathrm{L}$ & 0.62533 & $78.21 \%$ & IL, MLCT \\
\hline & & & & $\mathrm{H}-3 \rightarrow \mathrm{L}$ & 0.29739 & $17.69 \%$ & IL, MLCT \\
\hline & $\mathrm{S}_{0} \rightarrow \mathrm{T}_{1}$ & $2.58 \mathrm{eV}, 481 \mathrm{~nm}$ & 0.0000 & $\mathrm{H} \rightarrow \mathrm{L}$ & 0.42993 & $36.97 \%$ & IL, MLCT \\
\hline & & & & $\mathrm{H}-3 \rightarrow \mathrm{L}$ & 0.26116 & $13.64 \%$ & IL, MLCT \\
\hline
\end{tabular}

${ }^{a}$ Only the $\mathrm{S}_{1}$ and $\mathrm{T}_{1}$ states are presented. ${ }^{b}$ Oscillator strengths. And the oscillator strengths of the $\mathrm{T}_{1}$ states are zero because of the neglect of spinorbit coupling in time-dependent DFT calculations. ${ }^{c}$ Only the main configurations are presented. H and L denote HOMO and LUMO, respectively. ${ }^{d}$ The configuration-interaction coefficients (CI) are in absolute values. ${ }^{e}$ The contribution percentages of orbital transitions. Only the orbital pairs whose Co values above $10 \%$ are presented. ${ }^{f}$ IL: intraligand, LLCT: ligand-to-ligand charge transfer, MLCT: metal-to-ligand charge transfer. 

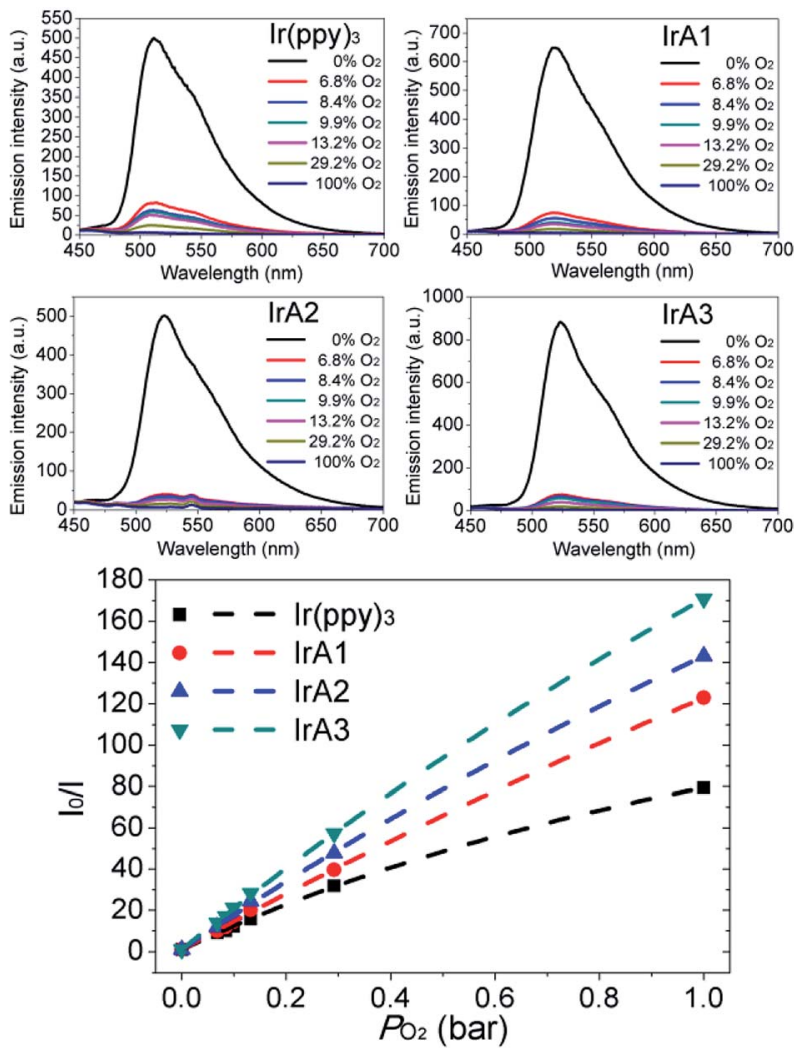

Fig. 4 Dependence of emission spectra and Stern-Volmer plots of all the $\operatorname{Ir}\left(\right.$ III) complexes; $10^{-5} \mathrm{M}$ in THF on oxygen concentration of $0-$ $100 \%, 25{ }^{\circ} \mathrm{C}$.

$$
\frac{I}{I_{0}}=\frac{\tau}{\tau_{0}}=\frac{f_{1}}{1+K_{\mathrm{SV} 1} p_{\mathrm{O}_{2}}}+\frac{f_{2}}{1+K_{\mathrm{SV} 2} p_{\mathrm{O}_{2}}}
$$

$f_{1}$ and $f_{2}$ are fractions of two microenvironments of the heterogeneous optical sensing system, respectively, which are defined as $f_{1}+f_{2}$ being $1 . f_{1}$ is the quenchable fraction with quenching rate constant $K_{\mathrm{SV} 1}$, and $f_{2}$ is the fraction which is not quenched at all with quenching rate constant $K_{\mathrm{SV} 2}$. Weighted quenching constant $K_{\mathrm{SV}}^{\mathrm{app}}\left(K_{\mathrm{SV}}^{\mathrm{app}}=f_{1} \times K_{\mathrm{SV} 1}+f_{2} \times K_{\mathrm{SV} 2}\right)$ is the guide of oxygen sensitivity of an optical oxygen sensor. The Demas' model is well-suited to describe homogeneity of oxygen sensing system. The Stern-Volmer constants for all the $\operatorname{Ir}(\mathrm{III})$ complexes in THF are summarized in Table S2 (see ESI $\dagger$ ). The $I_{0} /$ $I_{100}$ of IrA1-IrA3 and $\operatorname{Ir}(\text { ppy })_{3}$ are 122.9, 143.2, 170.8, and 79.4. And $K_{\mathrm{SV}}^{\mathrm{app}}$ are $138.6 \mathrm{bar}^{-1}, 171.4 \mathrm{bar}^{-1}, 204.8 \mathrm{bar}^{-1}$, and 119.6 bar $^{-1}$, respectively. IrA3 showed outstanding oxygen sensitivity in THF. Contrary to the sequence of phosphorescent lifetimes, the oxygen sensitivities are in the following order: $\operatorname{IrA} 3>\operatorname{IrA} 2>$ IrA1 $>\operatorname{Ir}(\text { ppy })_{3}$. Compared to $\operatorname{Ir}(\mathrm{ppy})_{3}$, the introduction of TPA substituents on cyclometalating ligand 2-phenylpyridine improved oxygen sensitivity of cyclometalated Ir(III) complexes. On the other hand, the increase of TPA substituents on metaposition of 2-phenylpyridine ligands (IrA1-IrA3) gradually improved the oxygen sensitivity (Fig. 4). Large quenchable fractions $\left(f_{1}\right)$ of IrA1 (0.999), IrA2 (0.998), and IrA3 (0.998) are higher than $\operatorname{Ir}(\mathrm{ppy})_{3}$ (0.985) which exhibited remarkable linearity of SVPs (Table S2, see ESI $\dagger$ ). With the introduction of TPA substituents at meta-position on 2-phenylpyridine ligands, $f_{1}$ values were steadily improved which caused more homogeneous microenvironment (high oxygen sensitivity) of cyclometalated Ir(III) complexes. The limit of detection (LOD) of all the cyclometalated Ir(III) complexes in THF was calculated of IrA1 (0.39 mbar), IrA2 (0.30 mbar), IrA3 (0.27 mbar) compared to $\operatorname{Ir}(\mathrm{ppy})_{3}(0.43 \mathrm{mbar})$ (see ESI $\dagger$ ).

From eqn (4), the ratio of collision radiuses $\left(\sigma_{1} / \sigma_{2}\right)$ of two emitters with different molecular structure under homogeneous microenvironment and uniform oxygen partial pressure is obtains by the expression, reads as (eqn (6))

$$
\frac{\sigma_{1}}{\sigma_{2}}=\frac{\left[\left(\frac{I_{0}}{I}\right)_{1}-1\right] \tau_{2}}{\left[\left(\frac{I_{0}}{I}\right)_{2}-1\right] \tau_{1}}
$$

The relationship between molecular structure and the collision radius have been investigated by parallelly measuring data of $I_{0}$ and $I_{100}$ five times. And results of bimolecular quenching process in THF and phosphorescent decay time of IrA1-IrA3 and $\operatorname{Ir}(\mathrm{ppy})_{3}$ were employed for analyzing the variation of collision radiuses (Fig. 5 and Table S3, see ESI $\dagger$ ). The ratio of collision radiuses are $\sigma_{\operatorname{IrA} 1} / \sigma_{\operatorname{Ir}(\text { ppy })_{3}}=1.27 \pm 0.05, \sigma_{\operatorname{IrA2} 2} / \sigma_{\operatorname{Ir}(\text { ppy })_{3}}=$ $1.72 \pm 0.10$, and $\sigma_{\mathrm{IrA} 3} / \sigma_{\operatorname{Ir}(\mathrm{ppy})_{3}}=2.13 \pm 0.07$, respectively. Comparision with $\operatorname{Ir}(\text { ppy })_{3}$, the collision radius of IrA1 can be obviously increased with the introduction of a TPA substituent at meta-position on benzene ring of 2-phenylpyridine ligand. And compared to IrA1, the progressive increase of TPA substituents on the rest of 2-phenylpyridine ligands strongly increased the collision radius of cyclometalated Ir(III) complexes (IrA2 and IrA3) as well which leading to higher collision probability between cyclometalated Ir(III) complexes and molecular oxygen, and provided potential oxygen sensitivity.

As a practical performance, IrA3 was composited with a thin film of silicon gel supported on a glass slide to construct a simple oxygen sensor. The phosphorescence of IrA3 oxygen sensor was totally quenched in air atmosphere and emitted bright yellow-green light under $\mathrm{N}_{2}$ stream. The quenchingemission response of IrA3 oxygen sensor is ultrafast and fully reversible that a flame-like light spot can be seen (Fig. 6).

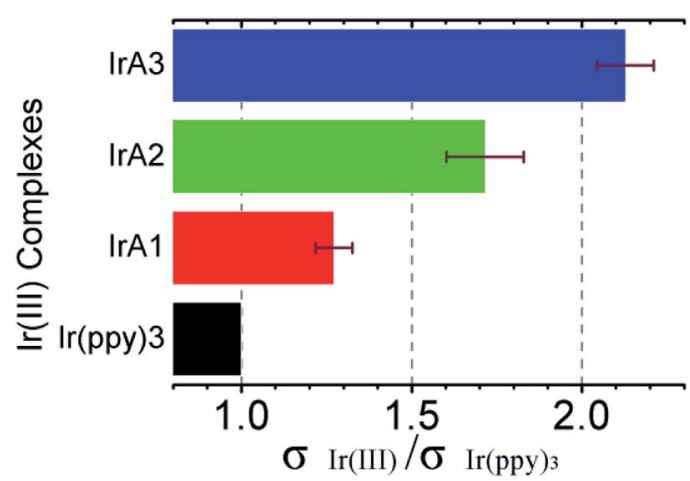

Fig. 5 The variation of collision radiuses of $\operatorname{IrA} 1-\operatorname{IrA} 3$ via $\operatorname{Ir}(\mathrm{ppy})_{3}$ for bimolecular quenching process. 


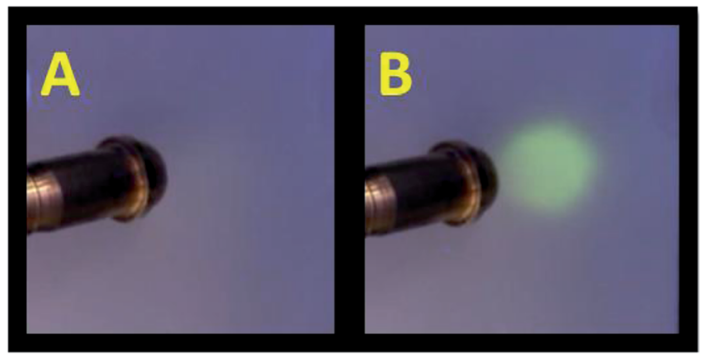

Fig. 6 (A) Photographs of a IrA3 oxygen sensor excited at $365 \mathrm{~nm}$ under air (B) with a nitrogen stream in copper pipe.

\section{Conclusions}

In conclusion, three TPA substituted cyclometalated Ir(III) complexes IrA1, IrA2, and IrA3 based on $\operatorname{Ir}(\mathrm{ppy})_{3}$ were synthesized and applied as phosphorescent probes for analysis of molecular oxygen. The phosphorescent intensity of $\operatorname{Ir}(\mathrm{III})$ complexes in THF was drastically changed by the oxygen concentration. IrA3 demonstrated the highest oxygen sensitivity with $I_{0} / I_{100}$ of $170.8, K_{\mathrm{SV}}^{\mathrm{app}}$ of $204.8 \mathrm{bar}^{-1}$, and LOD of $0.27 \mathrm{mbar}$. With the incremental introduction of TPA substituents at metaposition on 2-phenylpyridine ligands of $\operatorname{Ir}(\mathrm{ppy})_{3}$, the oxygen sensitivities of IrA1-IrA3 were obviously improved, and the $f_{1}$ values were gradually increased which caused more homogeneous oxygen sensing system and high oxygen sensitivity. The relationship between molecular structure and the collision radius of the emitter for optical oxygen sensing have been investigated and quantized through the cooperation of the Demas' model and the fundamental expression of luminescence quenching systems by oxygen. The incremental introduction of TPA substituents could effectively increase the collision radiuses of cyclometalated $\operatorname{Ir}(\mathrm{III})$ complexes which leading to more likely collision between the emitter and molecular oxygen, and provided high oxygen sensitivity. This research could potentially be applied as new prospect for molecular structure design of the emitter with high oxygen sensitivity for optical monitoring of molecular oxygen.

\section{Experimental}

\subsection{Materials and methods}

Unless otherwise noted, all the cross-coupling reactions for preparing the ligands were carried out in air. 2-Bromopyridine, (3-bromophenyl)boronic acid, (4-(diphenylamino)phenyl) boronic acid, phenylboronic acid, and iridium(III) chloride trihydrate were purchased from Adamas. Other chemicals were purchased from commercial sources and used without further purification. ${ }^{1} \mathrm{H}$ NMR and ${ }^{13} \mathrm{C}$ NMR spectra were recorded on a BRUKER AVANCE III HD $500 \mathrm{MHz}$ spectrophotometer. Mass spectra were recorded with a MALDI micro MX spectrometer. Phosphorescence lifetimes were determined on a Laser Flash Photolysis (LFP) (Dalian Institute of Chemical Physics). Absorption spectra were recorded by cary series 5000 UV-VisNIR spectrometer (Agilent Technologies). Emission spectra were recorded by cary eclipse G9800A fluorescence spectrophotometer (Agilent Technologies). Cyclic voltammograms were recorded on an electrochemical workstation PARSTAT 2273 (Princeton Applied Research) at room temperature.

\subsection{Synthesis section}

Synthetic procedure of 2-(3-bromophenyl)pyridine. A mixture of 2-bromopyridine ( $2.0 \mathrm{mmol}, 191 \mu \mathrm{L}), 1.5$ equiv. of (3bromophenyl)boronic acid $(3.0 \mathrm{mmol}, 482 \mathrm{mg}), 2$ equiv. of $\mathrm{K}_{2} \mathrm{CO}_{3}(4.0 \mathrm{mmol}, 548 \mathrm{mg}), \mathrm{Pd}(\mathrm{OAc})_{2}(1.5 \mathrm{~mol} \%, 0.03 \mathrm{mmol}$, $6.74 \mathrm{mg})$, ethanol/water $(6 \mathrm{~mL} / 2 \mathrm{~mL})$ was stirred at $80^{\circ} \mathrm{C}$ in air for indicated time. The reaction mixture was added to brine ( 15 $\mathrm{mL})$ and extracted four times with ethyl acetate $(4 \times 15 \mathrm{~mL})$. The solvent was concentrated and the product 2-(3-bromophenyl) pyridine was isolated by short-column chromatography on silica gel (200-300 mesh).

2-(3-Bromophenyl)pyridine. ${ }^{12}$ Yield: $53.2 \%$; colorless oil. ${ }^{1} \mathrm{H}$ $\operatorname{NMR}\left(500 \mathrm{MHz}, \mathrm{CDCl}_{3}\right): \delta 8.70(\mathrm{~d}, 1 \mathrm{H}), 8.17(\mathrm{~s}, 1 \mathrm{H}), 7.91(\mathrm{~d}, 1 \mathrm{H})$, $7.77(\mathrm{td}, 1 \mathrm{H}), 7.71(\mathrm{~d}, 1 \mathrm{H}), 7.54(\mathrm{dd}, 1 \mathrm{H}), 7.34(\mathrm{t}, 1 \mathrm{H}), 7.29-7.25$ $(\mathrm{m}, 1 \mathrm{H})$.

Synthetic procedure of ligand $N, N$-diphenyl-3'-(pyridin-2-yl)[1,1'-biphenyl]-4-amine (L1). A mixture of 2-(3-bromophenyl) pyridine $(0.25 \mathrm{mmol}, 58.25 \mathrm{mg}), 1.5$ equiv. of (4-(diphenylamino)phenyl)boronic acid ( $0.375 \mathrm{mmol}, 108.40 \mathrm{mg}), 2$ equiv. of $\mathrm{K}_{2} \mathrm{CO}_{3}(0.5 \mathrm{mmol}, 69 \mathrm{mg}), \mathrm{Pd}(\mathrm{OAc})_{2}(1.5 \mathrm{~mol} \%, 0.00375 \mathrm{mmol}$, $0.84 \mathrm{mg})$, ethanol/water $(3 \mathrm{~mL} / 1 \mathrm{~mL})$ was stirred at $80{ }^{\circ} \mathrm{C}$ in air for indicated time. The reaction mixture was added to brine ( 15 $\mathrm{mL})$ and extracted four times with ethyl acetate $(4 \times 15 \mathrm{~mL})$. The solvent was concentrated and the product L1 was isolated by short-column chromatography on silica gel (200-300 mesh).

L1. Yield: $84.2 \%$; white solid. ${ }^{1} \mathrm{H}$ NMR $\left(500 \mathrm{MHz}, \mathrm{CDCl}_{3}\right.$ ) $\delta 8.71(\mathrm{~s}, 1 \mathrm{H}), 8.20(\mathrm{~d}, 1 \mathrm{H}), 7.92(\mathrm{~d}, 1 \mathrm{H}), 7.77(\mathrm{~d}, 2 \mathrm{H}), 7.63-7.50$ $(\mathrm{m}, 4 \mathrm{H}), 7.26(\mathrm{~d}, 5 \mathrm{H}), 7.17-7.11(\mathrm{~m}, 6 \mathrm{H}), 7.07-6.98(\mathrm{~m}, 2 \mathrm{H}) .{ }^{13} \mathrm{C}$ $\operatorname{NMR}\left(126 \mathrm{MHz}, \mathrm{CDCl}_{3}\right) \delta 157.5,149.7,147.7,147.3,141.2,139.9$, $136.8,135.0,129.3,129.2,128.0,127.3,125.4,125.4,124.4$, 123.9, 122.9, 122.2, 120.7. HRMS (EI): calc.: $398.1783[\mathrm{M}]^{+}$. Found: $398.1780[\mathrm{M}]^{+}$.

Synthetic procedure of IrA1. The cyclometalating ligand 2phenylpyridine $(0.4 \mathrm{mmol}, 57 \mu \mathrm{L})$ was reacted with 0.6 equiv. $\mathrm{IrCl}_{3} \cdot 3 \mathrm{H}_{2} \mathrm{O}(0.24 \mathrm{mmol}, 84.5 \mathrm{mg})$ in a mixture of 2-ethoxyethanol and water $(9 \mathrm{~mL} / 3 \mathrm{~mL})$ at $105^{\circ} \mathrm{C}$ for $24 \mathrm{~h}$ to afford an iridium dimer, which was subsequently reacted with 0.6 equiv. of the cyclometalating ligand $\mathrm{L} 1(0.24 \mathrm{mmol}, 95.5 \mathrm{mg})$ and 5 equiv. of $\mathrm{Na}_{2} \mathrm{CO}_{3}(2 \mathrm{mmol}, 212 \mathrm{mg})$ in glycerol $(10 \mathrm{~mL})$ at $200{ }^{\circ} \mathrm{C}$ for $48 \mathrm{~h}$.

IrA1. Yield: 73.6\%; yellow acicular microcrystal. ${ }^{1} \mathrm{H}$ NMR (500 $\left.\mathrm{MHz}, \mathrm{CDCl}_{3}\right) \delta 7.96(\mathrm{td}, 2 \mathrm{H}), 7.86(\mathrm{~d}, 4 \mathrm{H}), 7.64(\mathrm{~d}, 2 \mathrm{H}), 7.58-7.54$ $(\mathrm{m}, 2 \mathrm{H}), 7.51(\mathrm{dd}, 2 \mathrm{H}), 7.27-7.20(\mathrm{~m}, 4 \mathrm{H}), 7.11(\mathrm{~d}, 10 \mathrm{H}), 6.98(\mathrm{dd}$, $3 \mathrm{H}), 6.85(\mathrm{dd}, 8 \mathrm{H}) .{ }^{13} \mathrm{C}$ NMR $\left(126 \mathrm{MHz}, \mathrm{CDCl}_{3}\right) \delta$ 166.7, 166.6, $161.3,147.9,147.1,147.1,145.9,144.3,143.7,137.4,137.1$, $135.9,129.9,129.2,127.1,124.7,124.0,123.9,122.5,122.1$, 121.9, 119.9, 119.8, 118.9, 118.8. HRMS (EI): calc.: 898.2647 $[\mathrm{M}]^{+}$. Found: $898.2646[\mathrm{M}]^{+}$.

Synthetic procedure of IrA2. The cyclometalating ligand L1 $\left(0.4 \mathrm{mmol}, 159.2 \mathrm{mg}\right.$ ) was reacted with 0.6 equiv. $\operatorname{IrCl}_{3} \cdot 3 \mathrm{H}_{2} \mathrm{O}$ $(0.24 \mathrm{mmol}, 84.5 \mathrm{mg})$ in a mixture of 2-ethoxyethanol and water 
$(9 \mathrm{~mL} / 3 \mathrm{~mL})$ at $105^{\circ} \mathrm{C}$ for $24 \mathrm{~h}$ to afford an iridium dimer, which was subsequently reacted with 0.6 equiv. of the cyclometalating ligand 2-phenylpyridine $(0.24 \mathrm{mmol}, 34.2 \mu \mathrm{L})$ and 5 equiv. of $\mathrm{Na}_{2} \mathrm{CO}_{3}(2 \mathrm{mmol}, 212 \mathrm{mg})$ in glycerol $(10 \mathrm{~mL})$ at $200{ }^{\circ} \mathrm{C}$ for $48 \mathrm{~h}$.

IrA2. Yield: $71.0 \%$; yellow acicular microcrystal. ${ }^{1} \mathrm{H}$ NMR $(500$ $\left.\mathrm{MHz} \mathrm{CDCl}_{3}\right) \delta 7.96(\mathrm{t}, 4 \mathrm{H}), 7.85(\mathrm{~d}, 4 \mathrm{H}), 7.61-7.54(\mathrm{~m}, 6 \mathrm{H}), 7.50$ (dd, 4H), 7.26-7.20 (m, 8H), 7.10 (d, 12H), 6.98 (dd, 8H), 6.85 (d, $4 \mathrm{H}) .{ }^{13} \mathrm{C}$ NMR $\left(126 \mathrm{MHz}, \mathrm{CDCl}_{3}\right.$ ) $\delta$ 166.8, 166.7, 148.0, 147.3, 147.2 , 146.0, 144.4, 143.8, 137.5, 137.2, 137.0, 136.1, 132.2, $130.0,129.9,129.3,128.6,127.2$, 124.8, 124.1, 122.6, 122.2, 120.1, 119.9, 118.9. HRMS (EI): calc.: $1141.3695[\mathrm{M}]^{+}$. Found: $1141.3692[\mathrm{M}]^{+}$.

Synthetic procedure of IrA3. The cyclometalating ligand L1 ( $0.4 \mathrm{mmol}, 159.2 \mathrm{mg}$ ) was reacted with 0.6 equiv. $\mathrm{IrCl}_{3} \cdot 3 \mathrm{H}_{2} \mathrm{O}$ $(0.24 \mathrm{mmol}, 84.5 \mathrm{mg})$ in a mixture of 2-ethoxyethanol and water $(9 \mathrm{~mL} / 3 \mathrm{~mL})$ at $105^{\circ} \mathrm{C}$ for $24 \mathrm{~h}$ to afford an iridium dimer, which was subsequently reacted with 0.6 equiv. of the cyclometalating ligand $\mathrm{L} 1$ (0.24 mmol, $95.5 \mathrm{mg})$ and 5 equiv. of $\mathrm{Na}_{2} \mathrm{CO}_{3}(2 \mathrm{mmol}$, $212 \mathrm{mg}$ ) in glycerol $(10 \mathrm{~mL})$ at $200{ }^{\circ} \mathrm{C}$ for $48 \mathrm{~h}$.

IrA3. Yield: $68.7 \%$; yellow acicular microcrystal. ${ }^{1} \mathrm{H}$ NMR $(500$ $\mathrm{MHz}, \mathrm{CDCl}_{3}$ ) $\delta 7.98(\mathrm{~d}, 3 \mathrm{H}), 7.87(\mathrm{~s}, 3 \mathrm{H}), 7.61$ (dd, 6H), 7.50 (d, $6 \mathrm{H}), 7.27-7.21$ (m, 9H), 7.11 (d, 24H), 6.98 (dd, 7.4 Hz, 9H), 6.92$6.88(\mathrm{~m}, 3 \mathrm{H}) .{ }^{13} \mathrm{C} \mathrm{NMR}\left(126 \mathrm{MHz}, \mathrm{CDCl}_{3}\right) \delta 166.8,166.7,148.0$, $147.3,146.0$, 144.4, 137.5, 136.9, 136.2, 129.3, 128.7, 128.6, 127.1, 124.7, 124.16, 124.1, 122.5, 122.2, 119.0. HRMS (EI): calc.: 1384.4743 [M] $]^{+}$. Found: $1384.4743[\mathrm{M}]^{+}$.

\subsection{Oxygen sensing}

The specific concentrations of oxygen in nitrogen at atmospheric pressure (from $\mathbf{0 - 1 0 0 \%}$ in volume fraction) were generated with two tube flowmeter. The volumetric flow rate was monitored by bubble flowmeter. ${ }^{10}$

\subsection{IrA3 oxygen sensor}

IrA3 was immobilized in a silicon gel plate (the layer thickness of silicon gel is $0.2 \pm 0.03 \mathrm{~mm}$; the granularity of silicon gel is 8 $\pm 2 \mu \mathrm{m}$ ) using thin-layer chromatography technic with IrA3THF eluent solution $\left(0.05 \mathrm{mg} \mathrm{mL} \mathrm{mL}^{-1}\right)$. The silicon gel oxygen sensor was dried for $4 \mathrm{~h}$ to remove THF before oxygen sensing tests.

\section{Conflicts of interest}

There are no conflicts to declare.

\section{Acknowledgements}

This work was supported by the funds of Liaoning Shihua University (2016XJJ-099, 2017XJJ-001) and the fund of Department of Education Of Liaoning Province (L2017LQN007).

\section{Notes and references}

1 A. Persson, E. Gross, P. Laurent, K. E. Busch, H. Bretes and M. de Bono, Nature, 2009, 458, 1030.
2 X. D. Wang and O. S. Wolfbeis, Chem. Soc. Rev., 2014, 43, 3666.

3 P. Lehner, C. Staudinger, S. M. Borisov and I. Klimant, Nat. Commun., 2014, 5, 4460.

4 A. Jana, B. J. Crowston, J. R. Shewring, L. K. McKenzie, H. E. Bryant, S. W. Botchway, A. D. Ward, A. J. Amoroso, E. Baggaley and M. D. Ward, Inorg. Chem., 2016, 55, 5623.

5 O. S. Wolfbeis, Adv. Mater., 2008, 20, 3759.

6 X.-d. Wang, J. A. Stolwijk, T. Lang, M. Sperber, R. J. Meier, J. Wegener and O. S. Wolfbeis, J. Am. Chem. Soc., 2012, 134, 17011.

7 M. Li, B. Zheng, D. Luo, H. Sun, N. Wang, Y. Huang, J. Dai, D. Xiao, S.-J. Su and Z. Lu, Chem. Commun., 2015, 51, 1926.

8 M. Amela-Cortes, S. Paofai, S. Cordier, H. Folliot and Y. Molard, Chem. Commun., 2015, 51, 8177.

9 Y. Wang, B. Li, Y. Liu, L. Zhang, Q. Zuo, L. Shi and Z. Su, Chem. Commun., 2009, 5868.

10 Y. Xing, C. Liu, X. Song and J. Li, J. Mater. Chem. C, 2015, 3, 2166.

11 Y. Liu, H. Guo and J. Zhao, Chem. Commun., 2011, 47, 11471. 12 Y. Xing, C. Liu, J.-H. Xiu and J.-Y. Li, Inorg. Chem., 2015, 54, 7783.

13 C. Liu, X. Lv, Y. Xing and J. Qiu, J. Mater. Chem. C, 2015, 3, 8010.

14 C. Liu, H. Yu, X. Rao, X. Lv, Z. Jin and J. Qiu, Dyes Pigm., 2017, 136, 641.

15 M. Quaranta, S. M. Borisov and I. Klimant, Bioanal. Rev., 2012, 4, 115.

16 O. S. Wolfbeis, J. Mater. Chem., 2005, 15, 2657.

17 Y. Amao, Microchim. Acta, 2003, 143, 1.

18 S. Tobita and T. Yoshihara, Curr. Opin. Chem. Biol., 2016, 33, 39.

19 C. A. DeRosa, S. A. Seaman, A. S. Mathew, C. M. Gorick, Z. Fan, J. N. Demas, S. M. Peirce and C. L. Fraser, ACS Sens., 2016, 1, 1366.

20 X. L. Qi, S. Y. Liu, R. B. Lin, P. Q. Liao, J. W. Ye, Z. Lai, Y. Guan, X. N. Cheng, J. P. Zhang and X. M. Chen, Chem. Commun., 2013, 49, 6864.

21 Y. Amao, T. Miyashita and I. Okura, J. Porphyrins Phthalocyanines, 2001, 5, 433.

22 C. Liu, X. Song, X. Rao, Y. Xing, Z. Wang, J. Zhao and J. Qiu, Dyes Pigm., 2014, 101, 85.

23 B. Lei, L. Wang, H. Zhang, Y. Liu, H. Dong, M. Zheng and X. Zhou, Sens. Actuators, B, 2016, 230, 101.

24 N. de Acha, C. Elosúa, D. Martínez, M. Hernáez, I. R. Matías and F. J. Arregui, Sens. Actuators, B, 2017, 239, 1124.

25 S.-Y. Liu, X.-L. Qi, R.-B. Lin, X.-N. Cheng, P.-Q. Liao, J.-P. Zhang and X.-M. Chen, Adv. Funct. Mater., 2014, 24, 5866.

26 X. Lu and M. A. Winnik, Chem. Mater., 2001, 13, 3449.

27 M. Nowakowska, J. Najbar and B. Waligóra, Eur. Polym. J., 1976, $12,387$.

28 A. Yekta, Z. Masoumi and M. A. Winnik, Can. J. Chem., 1995, 73, 2021.

29 L. K. Patterson, G. Porter and M. R. Topp, Chem. Phys. Lett., 1970, 7, 612.

30 J. E. Guillet and M. Andrews, Macromolecules, 1992, 25, 2752. 
31 J. N. Demas, E. W. Harris and R. P. McBride, J. Am. Chem. Soc., 1977, 99, 3547.

32 Y. Amao, K. Asai, T. Miyashita and I. Okura, Polym. Adv. Technol., 2000, 11, 705.

33 Y. Amao, T. Miyashita and I. Okura, Analyst, 2000, 125, 871.

34 Y. Amao, T. Miyashita and I. Okura, Anal. Chim. Acta, 2000, 421, 167.

35 M. E. Köse, B. F. Carroll and K. S. Schanze, Langmuir, 2005, 21, 9121.

36 W. Wu, C. Cheng, W. Wu, H. Guo, S. Ji, P. Song, K. Han, J. Zhao, X. Zhang, Y. Wu and G. Du, Eur. J. Inorg. Chem., 2010, 2010, 4683.

37 W. Wu, W. Wu, S. Ji, H. Guo and J. Zhao, Eur. J. Inorg. Chem., 2010, 2010, 4470.

38 W. Wu, W. Wu, S. Ji, H. Guo and J. Zhao, Dalton Trans., 2011, 40, 5953.

39 W. Wu, J. Sun, S. Ji, W. Wu, J. Zhao and H. Guo, Dalton Trans., 2011, 40, 11550.

40 M. Marín-Suárez, B. F. E. Curchod, I. Tavernelli, U. Rothlisberger, R. Scopelliti, I. Jung, D. Di Censo, M. Grätzel, J. F. Fernández-Sánchez, A. FernándezGutiérrez, M. K. Nazeeruddin and E. Baranoff, Chem. Mater., 2012, 24, 2330.

41 C. Liu, X. Song, Z. Wang and J. Qiu, ChemPlusChem, 2014, 79, 1472.

42 C. Liu, H. Yu, Y. Xing, Z. Gao and Z. Jin, Dalton Trans., 2016, 45, 734 .

43 H. Yu, C. Liu, X. Lv, J. Xiu and J. Zhao, Dyes Pigm., 2017, 145, 136.
44 X.-y. Xu, H.-n. Xiao and A.-P. Deng, Opt. Mater., 2014, 36, 1542.

45 Y. Lin, H. Wang, Y. Li, D. Zhu and X. Zhan, J. Mater. Chem. A, 2013, 1, 14627.

46 L. Wang, P. Shen, Z. Cao, X. Liu, Y. Huang, C. Liu, P. Chen, B. Zhao and S. Tan, J. Power Sources, 2014, 246, 831.

47 M. J. Frisch, G. W. Trucks, H. B. Schlegel, G. E. Scuseria, M. A. Robb, J. R. Cheeseman, G. Scalmani, V. Barone, B. Mennucci, G. A. Petersson, H. Nakatsuji, M. Caricato, X. Li, H. P. Hratchian, A. F. Izmaylov, J. Bloino, G. Zheng, J. L. Sonnenberg, M. Hada, M. Ehara, K. Toyota, R. Fukuda, J. Hasegawa, M. Ishida, T. Nakajima, Y. Honda, O. Kitao, H. Nakai, T. Vreven, J. A. Montgomery, J. E. Peralta, F. Ogliaro, M. Bearpark, J. J. Heyd, E. Brothers, K. N. Kudin, V. N. Staroverov, R. Kobayashi, J. Normand, K. Raghavachari, A. Rendell, J. C. Burant, S. S. Iyengar, J. Tomasi, M. Cossi, N. Rega, J. M. Millam, M. Klene, J. E. Knox, J. B. Cross, V. Bakken, C. Adamo, J. Jaramillo, R. Gomperts, R. E. Stratmann, O. Yazyev, A. J. Austin, R. Cammi, C. Pomelli, J. W. Ochterski, R. L. Martin, K. Morokuma, V. G. Zakrzewski, G. A. Voth, P. Salvador, J. J. Dannenberg, S. Dapprich, A. D. Daniels, O. Farkas, J. B. Foresman, J. V. Ortiz, J. Cioslowski and D. J. Fox, Gaussian 16, Revision A.03, Gaussian, Inc., Wallingford, CT, 2016.

48 E. Carraway, J. Demas and B. DeGraff, Anal. Chem., 1991, 63, 332.

49 E. Carraway, J. Demas, B. DeGraff and J. Bacon, Anal. Chem., 1991, 63, 337. 